\title{
Voluntary disclosure of intangible resources and stock proffitability
}

Clea Beatriz Macagnan

Univeridade do Vale do Rio dos Sinos (Brasil) cleabeatriz@hotmail.com

Received November, 2008

Accepted J anuary, 2009

\section{Abstract:}

The present study analyzes the extent of voluntarily disclosed information about intangible resources, in the annual report of companies from Spain's capital market, as well as the possibility of there being a correlation between that disclosure and the effective profitability of the stock. In methodological terms, the present research has used semiotic analysis, in order to construe indicators and indexes, and the technique of logistic regression, to analyze the probability of the implication between disclosure and stock profitability. The considerations that were established go against the assumption that the extent of voluntarily disclosed information results in greater stock profitability, in the year following the publication of the company's annual report, when results are found to be higher than average. On the other hand, the analysis presents statistically meaningful results, recognizing the probability of a decrease in stock profitability, in the year following the publication of information.

Keywords: voluntary disclosure, information, stock profitability 


\section{Introduction}

The consequences of voluntarily disclosing information about intangible resources over the cost of capital and, therefore, of the effective profitability of stock is a theme that has not been, so far, the object of many studies, although it is of great importance for the capital market and for the institutions that regulate it. The difficulty of measuring the extent of voluntarily disclosed information about intangible resources, as well as the limitations found in treating them by using accounting tools restrains, to a great extent, the development of empirical studies. The expression intangible resources is used here to mean the same as knowledge and intellectual capital. They are resources that generate value, with no physical substance, generated through material or financial investment, through innovation and peculiar organizational designs for the management of human resources. The expression intangible resources has been chosen instead of immaterial active, because the latter demands a treatment with accounting techniques.

In the attempt to contribute to the development of the field, the present research analyzes the probability of finding a correlation between the extent of voluntarily disclosed information about intangible resources, in the annual report of 2002, and the effective profitability of stock, in the following year. The sample consists of 91 non-financial companies, listed in the Bolsa de Madrid.

In methodological terms, the present research has used of techniques from semiotic analysis. Semiotic is "sciences general of all of the systems of signs" (Coelho Netto, 1990: 17). In order to construe indicators and indexes, this made it possible to identify the extent of voluntarily disclosed information about intangible resources. In order to analyze the probability of finding a correlation between the extent of voluntarily disclosed information about intangible resources and stock profitability, the technique of logistic regression analysis has been used.

The results go against the assumption that the extent of voluntarily disclosed information about intangible resources means greater stock profitability in the year following the publication of the annual report of the companies. On the other hand, the analysis presents statistically meaningful results, recognizing the probability of there being a decrease in profitability of stock in the year following the disclosure of information on tangible resources. 
The present article is structured in five parts. After the introduction, the theoretical assumptions, the research problem, the objective of the research, and the formulation of the hypothesis, are presented. After that the methodology used is described, identifying the sample, the data sources and the analysis technique, as well as the models, used in the research. Moreover, the variables are described. In the end, the results are analyzed and some possible conclusions are discussed.

\section{Review of previous work and development of a hypothesis}

On the one hand, neoclassic economic theory maintains that the market works in perfect competition. From another theoretical perspective, the market presents imperfections, such as the tendency to concentration, uncertainty and risk, unbalanced income distribution and asymmetrical information (Arrow, 1963). This point of view recognizes the company in its structural complexity, as an organization comprising a contact network (Jensen \& Meckling, 1976). Such an organization is defined as developing activities aiming at the procurement of gain, established by resources and capacities: tangible and intangible, aligned by the responsibilities of the involved parts in the contracts that sustain it. When it comes to private companies, the main objective is the maximization of its value (Coase, 1971; Jensen \& Meckling, 1976; Hughes, 1986; Core, 2001; Williamson, 2002b; Suárez, 2003; Brealey \& Myers, 2005; Copeland et al., 2005; Roos et al., 2005), represented by capital gains and dividend gains (Copeland et al., 2005), identified by the effective profitability of the company's stock, the investor's main objective. In the economic studies reviewed, it has been observed that intangible resources are an important differential for the maximization of the company's value. For this reason, a choice has been made to analyze the disclosure of representative information on intangible resources. Intangible actives come from the theory of resources and capabilities. Resources are "all activities, capacities, organizational processes, company attributes, information, knowledge, etc. controlled by the company, capacitating it to create and implement strategies to improve efficiency and effectiveness" (Barney, 1991: 101). In other words, the resources of a company may be tangible (financial and physical), human (abilities and knowledge, capacity for communication and collaboration and motivation) and intangible (technology, reputation and culture). (Habbershon \& Williams 1999; Grant, 2005). When the value of information is recognized, this becomes intangible capital, integrating the resources of a company. Since in an environment of uncertainty 
information is seen as a product, in an economic context it becomes value (Arrow, 1962).

The point of departure is the principle that investors are essentially capital providers, not the owners of a company, to the extent that stockholders have stock, not the whole corporation (Demsetz, 1967). The investor is committed to the capital, providing resources for the working of the company, whereas the manager administrates such resources, choosing their destination within the organization. Therefore, the administrator, because he retains both control and established decision-making power within a previously agreed upon time framework, determines the application of those resources, according to his or her parameters of choice, establishing new economic conditions for the organization. As stockholders or investors are not informed about the new economic conditions, there arises an informational asymmetry between them and the manager. Information is one of the most important factors for market efficiency. Asymmetric information, inherent to exchange relations, causes market inefficiency, giving room for the possibility of greater gain for some and lesser gains for others (Akerlof, 1970).

The existence of asymmetry of information would suggest the appearance of problems related to adverse selection and moral risk. The problem of adverse selection arises before the contract is signed, and occurs whenever one of the parties withholds private information. The other party is then subject to adverse selection, to the extent that it does not have the information necessary for a better assessment of the object of interchange. The problem of adverse selection (may) arise whenever a contractor is free to buy (or not), to choose the amount of the purchase, and continue the interchange or to abandon the transaction (Akerlof, 1970), as in the case of stock acquisition in the capital market. The problem is minimized by the reduction of the asymmetry of information, made possible by its disclosure.

In contrast to the problem of adverse selection, moral risk appears after the signing of the contract, and means uncertainty increased by the possibility of negative results (risks) with the behavior (immoral problematic) between the parties of a contract. This arises when the action of the agent is not verifiable (Arrow, 1963). In the contracts of the capital market, it means the possibility of 
the company's administration to choose to pursue other objectives (whether they be personal or not) instead of those held by external stockholders. Whereas stockholders aim at the maximization of the company's value, administrators may focus on protecting their own interests, such as personal income, power, security, professional recognition, continued education of the staff, among others (Brealey \& Myers, 2005), as well as establishing a different position toward the problem of risk.

In theory, those problems may create transactional costs, related to the increase of investment risks, resulting in capital costs, mainly of companies with greater financing needs; the under- or over-valuation of stock, especially the intangible resource-intensive ones; the use of privileged information, allowing the manipulation of information; benefiting the big stockholders over the small ones; the increase in volatility and decrease in stock liquidity (Firth, 1984; Chow \& WongBoren, 1987; Cooke, 1989; Christopher \& Hassan, 1995; Hossain et al., 1995; Botosan, 1997; Sengupta, 1998; Aboody \& Lev, 2000; Leventis \& Weetman, 2000; Watson et al., 2002; Nagar et al., 2003; Firer \& Williams, 2006).

The recognition of the existence of asymmetry of information could generate reactive behavior both by investors and stockholders, as well as by administrators. An investor's reaction could be demanding greater capital gains, since he or she does not have the information allowing better assessment of the risk of the investment, which would result in transactional costs. That is due to the fact that the cost of information is the main component of transactional costs (Coase, 1998). In an environment of uncertainty, information is a product, since in the economic context it becomes economic value, in the sense that anyone who has information may obtain greater gains (Arrow, 1962).

On the other hand, to the extent that an administrator deems this behavior as possible, he or she may voluntarily disclose information, aiming at establishing a trust relationship with the stockholders or investors (Botosan, 1997; Marr, 2005), altering the investors' perception about the risk of the active's return, and promoting greater liquidity in the stock market (Copeland \& Galai, 1983; Glosten \& Milgrom, 1985; Diamante \& Verrecchia, 1991; Botosan, 1997; Healy \& Palepu, 1999; Lambert et al., 2006). Information disclosure may belong to one of three categories (Healy \& Palepu 1999): obligatory financial demonstration; voluntary 
disclosure by administrators and information from third parties. However, disclosure is normally referred to as being either compulsory or voluntary, since information from third parties is mediated by analysts or journalists. If on the one hand compulsory disclosure is regulated by legislation and by the rules of accounting - formal institutions, voluntary disclosure depends on the motivations of the company's administrators. Thus, all information disclosed by initiative of the company's directors, unless it is compulsory, due to external regulation, is considered, basically, as voluntary. Since compulsorily disclosed information is the same for all companies within a market, we may assume that it is voluntarily disclosed information that makes the difference among companies. Thus, the disclosure of information may mean gains through the expansion of liquidity, lesser volatility, reduction of costs of capital and, consequently, greater profitability of stock in the capital market.

However, there is no consensus concerning information disclosure when it comes to stating that this would bring about, necessarily, the procurement of gains. Another theoretical perspective departs from the assumption that disclosure of information establishes costs for the company (Verrecchia, 1983; Dye, 1986; Fishman \& Hagerty, 1988; Wagenhofer, 1990; Darrough \& Stoughton, 1990; Lev, 1992; King \& Wallin, 1995; Camfferman, 1997; Depoers, 2000; Williams, 2001; Vergauwen \& Alem, 2005). Those are divided into direct and indirect costs. Direct costs are the effort to process and spread information. In other words, those are the costs established by material and human values needed for the activity of identification, systematization and publication of information. Indirect costs are related to three situations: (1) negative impact, in the perception of investors, of disclosed information; (2) litigation costs; (3) loss of competitive advantages, due to the disclosure of certain pieces of information making it possible for competitors to react strategically, promoting a decline in the profitability of stock. The representation of the consequences of the voluntary disclosure of information, following different theoretical perspectives, is summarized in Figure 1.

Therefore, the decision to voluntarily disclose information might have different consequences, depending on the theoretical perspective one adopts. This is proof enough of the difficulties institutions have to face when they have to establish norms aiming at obtaining a smooth market performance, as well as how difficult it is for administrators to establish disclosure policies, which seems to justify the 


\section{Intangible Capital}

relevance of the present research. Moreover, a mention may be made of the limited amount of empirical research about the implications of the extent to which one has decided to voluntarily disclose information (such as the ones carried out by Botosan, 1997; Sengupta, 1998; Richardson \& Welter, 2001; Botosan \& Plumlee, 2002; Hail, 2002; Gietzmann, 2003), analyzing both compulsorily and voluntarily disclosed information, going farther than the analysis of merely tangible resources. Resources are "all activities, capacities, organizational processes, company attributes, information, knowledge, etc. controlled by the company, capacitating it to create and implement strategies to improve efficiency and effectiveness" (Barney 1991: 101). In other words, the resources of a company may be tangible financial and physical; human - abilities and knowledge, capacity for communication and collaboration and motivation and intangible - technology, reputation and culture (Habbershon \& Williams 1999; Grant 2005). This information is considered as strategic, because it is a competitive differential, which maximizes the company's value.

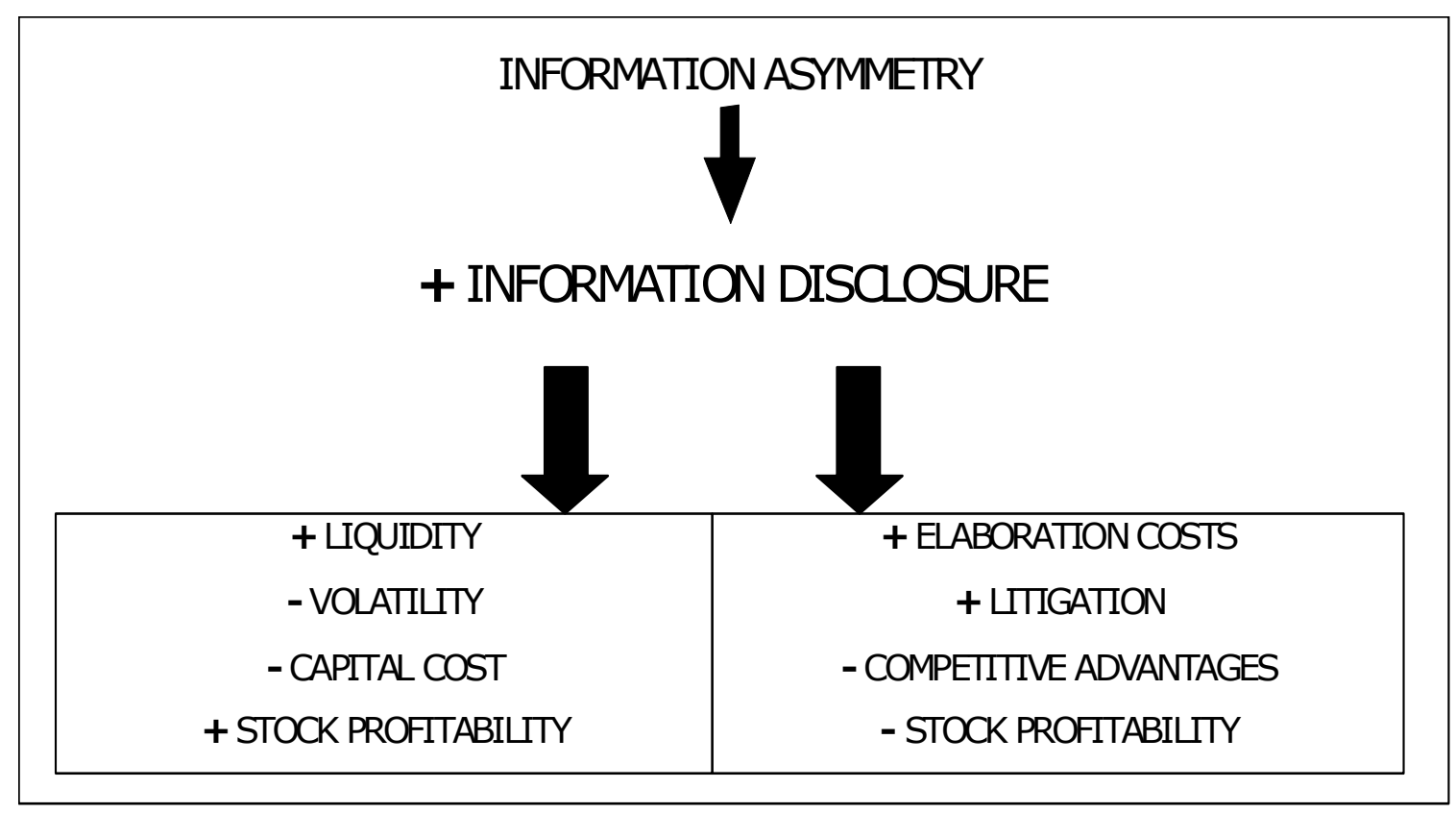

Figure 1: Consequences of information disclosure 
It is necessary to know the consequences, both private and social, of disclosing information about intangible resources (Lev, 1997; Fields et al., 2001). In January 2002, the Financial Accounting Standards Board (FASB) created a committee aiming at discussing the implications related to those topics: the disclosure of information and intangible actives. Among different arguments, the commission highlights a concern toward investigating: "What are the costs and benefits of disclosing information about intangible actives?" (Financial Accounting Standards Committee, 2003: 183) There is very little evidence about the reduction of capital costs from the disclosure of information (Lev, 2003).

Therefore, the issue that identifies the problematic of information disclosure concerning intangible resources over stock profitability is: "Is there a relationship between the extent of voluntarily disclosed information and the profitability of a company's stock, in the following year?" So, the hypothesis to be tested is:

Ho: There is a positive relationship between the voluntary disclosure of information and the effective profitability of stock obtained in the following year.

Thus, this research aims at verifying the investors' behavior, from the perspective of the identification of the communicative behavior of the administrator, made possible by the analysis of the probability of there being an implication between the extents of the disclosure of information on intangible resources.

\section{Methodology}

\section{Characterization of the sampling}

The population analyzed consists of 110 individuals, that they integrate the Mercado Continuo, whereas the sample comprises 91 companies with stock on the Spanish market, as seen in Appendix 1. Most companies excluded from the sampling belong to the financial sector (e.g. banks, insurance companies and state-owned savings banks). The banks and insurance companies follow an international normative orientation different from the companies of other segments, for this reason they were excluded of the sample. Only seven companies have been excluded due to insufficient information. All companies in the sampling belong to the general index of the Bolsa de Madrid; they also took part in IBEX 35 
in 2002. This number of companies represents $83 \%$ of the population, which ensures the representational dimension of the sample.

An important feature of the sampling is its balance, in terms of representation of the four market sector to which the companies analyzed belong. The sectors are: (1) basic industry, including the extractive industry, steel metallurgy, and energy and metal transformation. Those are large-scale companies, usually with some kind of state intervention (price regulations or subventions), performing their activities focused on basic products for the economy; (2) manufacturing industry, comprising companies that manufacture goods, usually targeted at consumers; (3) the building industry, including constructors, cement producers and furniture factories; (4) commerce, services and transportation, comprising companies from the fields of commerce, services in general and transport. The manufacturing sector is the best represented, with 28 companies ( $30 \%$ of the total of the sample); the building sector is the least present in the sampling, with 19 companies ( $20 \%$ of the total of the sampling).

\section{Data sources}

The development of this research involved searching for data from different sources. Among them, annual company reports may be mentioned, as well as databases from SABI (the Iberian System of Balance Sheet Analysis), electronic pages, Internet sites, Bolsa de Madrid, CNMV (the National Committee of the Stock Market), the Spanish Stock Market Society (Infobolsa), the Barcelona Stock Market and the databases from ABI/Inform Global, Business Source Premier, and ECOMLIT, apart from work documents presented in Congresses and published on the Internet. This resulted in two different kinds of data: primary and secondary sources.

The annual reports, concerning 2002, published on a website, of companies included in the sampling, are the primary source of data. The annual report has been chosen because it is the most usual communication medium used by companies (Camfferman, 1997). Those data were used to constitute the explanatory variables which identified the extent of information disclosure on intangible resources. 


\section{- Intangible Capital}

The other resources were used for building up the dependent variables: effective profitability of stock in 2003; and control variables: the value of the capitalization, beta and the result of the accounting value, divided by the price of the stock, in 2003.

\section{Analysis technique}

The technique chosen is that of logistic regression, with the profitability of stock in 2003 (Rentadic3) as the dependent variable.

The explaining variables (Dtri2; Dcr2; Dce2; Dch2; Dcet2; Dceo2; Dcrn2 and Dcrs2), represent the extent of information disclosure measured from the index of a category or subcategory of indicators, representing intangible resources, disclosed in the annual report of 2002, as seen below in more detail.

The models are also composed by control variables. Based on the review of research done on the implications of disclosure, three control variables have been chosen to be included in the models. Those are: (1) the company's beta for 2003 (Beta3), representing investment risk for that year; (2) the value of capitalization in 2003 (Capital3), since stock profitability may be influenced by the size of the company; and (3) the results of the accounting value divided by the price of stock, in 2003 (Valor3), indicating the proportion between the capital owned by the company and its value on the market.

\section{Dependent variable}

Dependent variable Rentadic3 identifies the profitability of company stock, obtained in 2003. The values are obtained through the calculation of the difference between the final value of the stock and its initial value, in 2003, plus the dividend and the preference rights for subscription, acquired in the same year.

$$
R_{j t 1}=\frac{\left(P_{j t 1}-P_{j t 0}\right)+(D+D P S)}{P_{j t 0}}
$$

Equation 1: The profitability of company stock 
This variable may be described as dichotomous, classifying companies based on the following criteria: (1) those which obtain profitability in the year in question, which is greater than the average of the sampling and (2) those which obtain profitability in the year in question, which is smaller than the average of the company sampling. Those with values over the average have the fixed value of $(1)$; those with values below average have the fixed value of $(0)$.

\section{Disclosure index of intangible resources}

For the configuration of the explaining variables, some critical factors have been found. The first refers to the nature of the intangible resources that are not defined by materiality, but rather by knowledge and information. Moreover, since there is no accounting normative to guide the recognition and treatment of all the intangibles as assets, even though they represent economic resources owned by the companies, creating an objective difficulty of recognition and measurement of intangible resources. Accounting norms from the International Accounting Standard Committee (IASC - a NIC 38) and from the Financial Accounting Standards Board (FASB), paragraph 9 from statement number 17; Accounting Principles Board (APB), guiding the accounting treatment of immaterial resources as assets with limitations. Those are intangible resources which integrate the difference between the accounting value and the price of stock on the market.

Another critical factor for the development of this research was the fact that disclosure is an abstract concept and cannot be directly measured, since it does not have the characteristics inherent to the determination of its intensity or quality. Those difficulties led us to perform two different kinds of literature review: (1) one enabling us to recognize intangible resources and (2) different ways of measuring the extent of voluntarily disclosed information. Concerning the first difficulty, the reviewed theoretical and empirical literature about disclosure recognizes intangible resources through representative indicators. Important to highlight that there is not appear a generally accepted classification of the intangible (Cañibano et al., 2000).

As for the second difficulty, empirical research makes use of indexes, representing categories of information indicators, in order to measure their disclosure extent. Those are known as the most frequently used and accepted instrument to measure the extent of disclosure in the reviewed empirical research projects (Botosan, 
1997; Garcia-Meca \& Martínez, 2004). Some research projects make use of indicators and indexes of information obtained from databases, constructed by organizations such as the Association for Investment Management and Research (AMIR), among others. When there are no indicators or indexes available though databases, as in the present research project, those are constructed by the researchers themselves. The indicators are enunciated as representing the information that one wishes to analyze, and the index is constructed based on a selection of information, through categories, making it possible to obtain an average of the extent of disclosure.

There are no indicators of intangible resources and indexes representing the extent of disclosure, in the annual reports of companies in the capital market of Spain. So, the construction of indicators has been developed. In order to do so, a recognition and identification process of representing indicators of intangible resources has been established, validated through theoretical and empirical literature, allowing us to observe the existence of great variety, both in form and in content, among the reviewed studies. After that, a quantitative analysis process has been developed, making use of the technique of semiotic analysis, aiming at identifying the signification of each indicator pointed out by the literature. This analysis allowed us to recognize the indicators, comprising the representation of the whole contents of the analysis, representing the intangible resources. Then, those indicators were contrasted, in a sampling of thirteen annual reports, aiming at obtaining an empirical reference from them. Moreover, factorial analysis has been developed, aiming at examining the underlying structure of this set of indicators and condensing the information obtained in this way. The results of the analysis did not allow us to find common factors between indicators. Thus the existence has been confirmed of 123 representing indicators of intangible resources, to be used in the present research project, listed in Appendix 2.

One of the aspects of the criticism that may be opposed to the use of an index for the analysis of the extent of information disclosure is that it lacks objectivity, especially when constructed by the researchers themselves. This problem is even more serious if one is dealing with voluntarily disclosed information. If, on the one hand, those limitations have to be recognized, it is also important to bear in mind that the indexes, as well as the indicators, have been widely accepted, inasmuch as they make a contribution as useful tools for the cognition of a reality that can only 
be approached through representation (Sveiby, 2000). One of the main advantages of the use of indexes is that it allows us to make use of statistical techniques (Botosan, 1997).

Taking into consideration the aforementioned qualifications, some procedures have been adopted, in constructing the indexes, such as that of reviewing the theoretical and the empirical literature about categories of intangible resources, allowing us to recognize and elaborate indexes that represent the indicators. This review made it possible to verify the existence of a wide variety, both in form and content, of the representational categories of indicators concerning intangible resources. Again, the semiotic analysis has been developed aiming at identifying the content of those categories, representing the diversity of indicators related to intangible resources, which then become indexes.

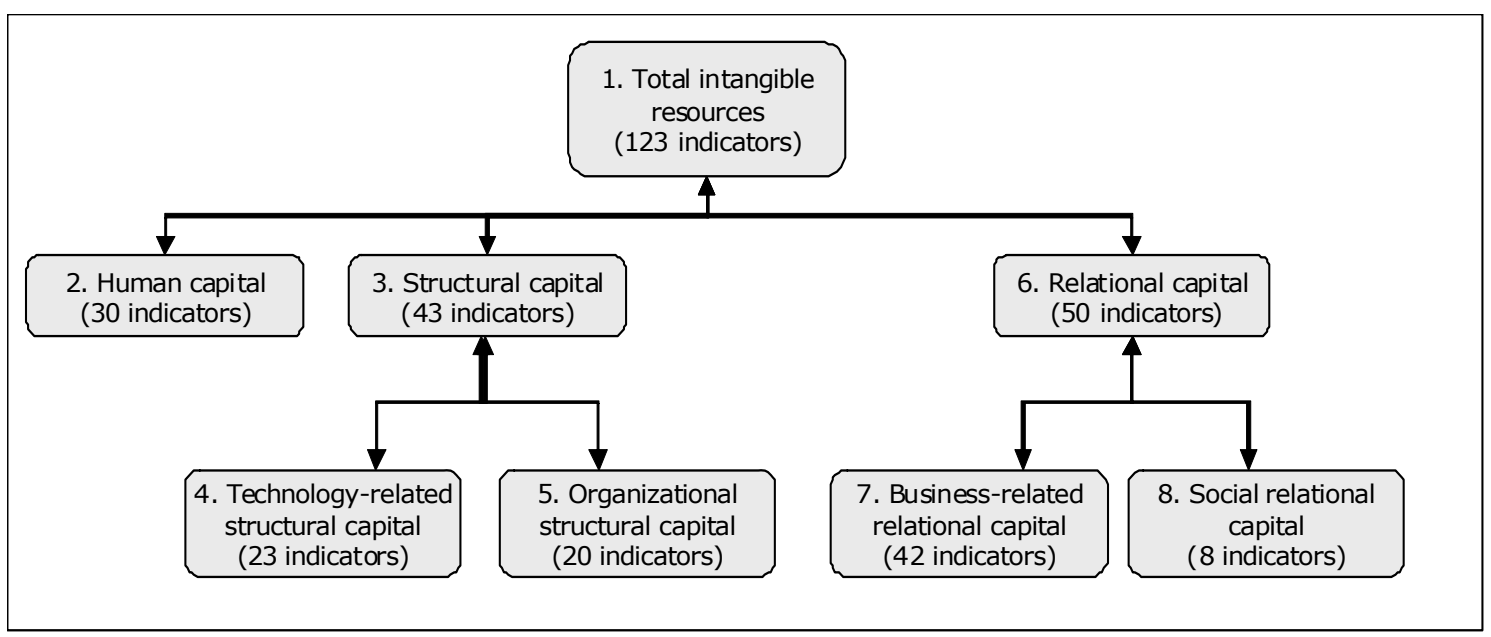

Figure 2: Categories and subcategories, with the number of indicators representing intangible resources

Category (1), total of intangible resources, has a total of 123 indicators, integrating three other categories: human capital, structural capital and relational capital (Sánchez et al. 2000). Category (2), human capital "is defined as the knowledge that employees take with them when they leave the firm. It includes the knowledge, skills, experiences and abilities of people" (Cañibano et al., 2002: 63) and this research comprises 30 indicators. Category (3), structural capital "is defined as the knowledge that stays within the firm at the end of the working day. It comprises the organizational routines, procedures, systems, cultures, databases,etc." (Cañibano et al., 2002:63), adding up to a total of 43 indicators. 
Subcategory (4), technology-related structural capital, represents the company's technological values, and comprises 23 indicators, which are an essential part of the company's structural capital. Subcategory (5), organizational structural capital, represents the management system, as well as all the technical and organizational activity implemented by the personnel; it comprises 20 indicators. Category (6), relational capital, "is defined as all resources linked to the external relationships of the firm, with customers, suppliers or R\&D partners. It comprises that part of Human and Structural Capital involved with the company's relations with stakeholders (investors, creditors, customers, suppliers, etc.), plus the perceptions that they hold about the company" (Cañibano et al., 2002: 63), totaling 50 indicators. Subcategory (7), business-related relational capital, represents the values established by the ability to interact with the market, including 42 indicators, which are an essential part of the company's relational capital. Subcategory (8), social relational capital, comprises 8 different indicators, which also form an essential part of the company's relational capital.

\section{Validity of extent indexes for disclosure of intangible resources}

The categories and subcategories described above are transformed into representative indexes to indicate the extent to which intangible resources indicators have been disclosed. Therefore, for each indicator comprising the respective category, the value of (1) has been determined when information is disclosed and ( 0 ) when it is not. This criterion may be challenged if it is considered that the disclosed information may have different values in different cases. For this reason, some studies make use of weighted criteria, established by the researcher, by analysts or through other means. Most empirical studies do not make use of a weighted system (Leventis \& Weetman, 2000). Prencipe's research (2004), which studies this aspect, obtains similar results for weighted and non-weighted indicators. Therefore, the use of a weighted system has been put aside, following the methodology used by Cooke (1989, 1992), Wagenhofer (1990), Hossain et al. (1995), García and Monterrey (1993), Raffournier (1995), Apellániz and Sardoya (1995), Williams (2001) and Gómez et al. (2006).

The calculus used to elaborate each information disclosure index takes the following form: the number of expected indicators for each company corresponds to $n_{j}$, the company is represented by subindex $j$, and the number of indicators is 
expressed by $\mathrm{i}$. When the indicator $\mathrm{X}_{\mathrm{ij}}$ is revealed, it receives the value of 1 , and 0 if it is not revealed.

$$
I_{j}=\frac{\sum_{i=1}^{n} x_{i j}}{n_{j}}
$$

Equation 2: Disclosure index

Another point that must be emphasized is the difference between the absence of an indicator and its non-disclosure. On the one hand, one may have a case where the indicator is irrelevant to the company, as in the example of a company that sells an extremely large number of products, for which their individual price is not considered an important piece of information (e.g. Carrefour). On the other hand, the question arises whether the company discloses such information (or not). Such situations were taken into consideration and indexes were constructed that were adjusted to each individual case. The total value of a company's indicators was calculated, divided by the maximum number that could be obtained, and multiplied that by 100 . The obtained variation goes from 0 to 100 of the result of the constructed index. Subsequently, those indicators and indexes were submitted to a validation process by five researchers in the field, based on a procedure used by Macagnan (2005).

\begin{tabular}{l|l} 
Variables & Cronbach's Alfa \\
\hline Total intangible resources & 0.938 \\
\hline Human capital & 0.818 \\
\hline Structural capital & 0.892 \\
Technology-related structural capital & 0.826 \\
Organizational structural capital & 0.796 \\
\hline Relational capital & 0.868 \\
Business-related relational capital & 0.859 \\
Social relational capital & 0.798
\end{tabular}

Table 1: Cronbach's Alfa statistics of disclosure indexes - explaining variables

Cronbach's Alfa test was applied, aiming at measuring the internal coherence of the constructed indexes, which indicates the trustworthiness of such measurements when many items are used, as in this study. Values below 0.7 
generally indicate low internal consistency. The results obtained in this research are presented in Table 1, where one may observe the existence of internal coherence in the constructed indexes.

\section{Analysis of empirical results}

\section{Descriptive analysis}

\begin{tabular}{|c|c|c|c|c|c|}
\hline Variables & $\mathrm{N}$ & Average & $\begin{array}{c}\text { Typical } \\
\text { deviation }\end{array}$ & Minimum & Maximum \\
\hline Dcr2 (Relational capital*) & 91 & 29.75 & 16.96 & 0.00 & 79.07 \\
\hline Dch2 (Human capital*) & 91 & 18.86 & 13.38 & 0.00 & 56.67 \\
\hline Dcet2 (Technology-related structural capital*) & 91 & 29.79 & 17.08 & 0.00 & 82.61 \\
\hline Dceo2 (Organizational structural capital*) & 91 & 26.70 & 17.72 & 0.00 & 75.00 \\
\hline Dcrn2 (Business-related relational capital*) & 91 & 23.02 & 13.93 & 2.38 & 66.67 \\
\hline Logvalor3 (logarithm accounting value divided by stock price**) & 91 & 0.12 & 0.45 & -0.69 & 1.86 \\
\hline Capital3 (capitalization**) & 91 & 3119195 & 7698092 & 13379 & 57686575 \\
\hline Logcapital3 (logarithm capitalization**) & 91 & 13.39 & 1.85 & 9.50 & 17.87 \\
\hline Beta3 (Beta**) & 80 & $0.25 * * *$ & 0.24 & -0.17 & 0.86 \\
\hline
\end{tabular}

$*$ Values for 2002

$* *$ Values for 2003

*** The companies with higher liquidity were those that

integrate IBEX 35; however, the majority of companies in the

sampling have low liquidity, which helps explain the Beta average.

Table 2: Statistics describing indexes representing the extent of disclosure of information related to intangible resources (explaining variables) and control variables.

The results of the descriptive analysis are presented in Table 2, where it is shown that the highest average is that of the variable representing the social capital (Dcrs2), with $44.92 \%$ of disclosed indicators. On the other hand, the lowest average is that of human capital (Dch2), with $18.86 \%$ of disclosed indicators. The control variable of human capital (Capital3) presents a deviation typically higher than the average, which led us to transform it into logarithms. Since the control variable of accounting value divided by stock value (Valor3) did not range below average when transformed into logarithms, the choice has been made to make use of it without the transformation.

Appendix 1 shows percentages of indicators of intangible resources disclosed in the 2002 annual report; there, the most frequently disclosed indicators are: (1) those representing the number of employees, with $89.4 \%$; and (2) the characteristics of provided products, with $88.3 \%$. 


\section{Analysis of correlations}

Table 3 shows the explanatory variables: total of intangible resources (Dtai2), Relational capital (Dcr2), Structural capital (Dce2), Technology-related structural capital (Dcet2) and Organizational structural capital (Dceo2), which represent the extent of indicator disclosure on intangible resources, with correlation coefficients compromising the inclusion of those into the same regression model.

\begin{tabular}{|c|c|c|c|c|c|c|c|c|c|c|c|}
\hline $\begin{array}{l}\text { Dtri2 } \\
\text { Dcr2 } \\
\text { Dce2 } \\
\text { Dch2 }\end{array}$ & $\begin{array}{l}\text { Dtri2 } \\
1 \\
.891 * * \\
.896 * * \\
.767 * *\end{array}$ & $\begin{array}{l}1 \\
.660 * * \\
.554 * *\end{array}$ & $\begin{array}{l}1 \\
.587 * *\end{array}$ & Dch2 & Dcet2 & Dceo2 & Dcrn2 & Dcrs2 & Valor3 & Beta3 & Logcapital3 \\
\hline Dcet2 & $.891^{* *}$ & $1.000 * *$ & $.660 * *$ & $.554 * *$ & 1 & & & & & & \\
\hline Dceo2 & $.847 * *$ & $.921 * *$ & $.649 * *$ & $.541 * *$ & $.921 * *$ & 1 & & & & & \\
\hline Dcrn2 & $.806 * *$ & $.575 * *$ & $.941 * *$ & $.491^{* *}$ & $.575 * *$ & $.584 * *$ & 1 & & & & \\
\hline Dcrs2 & $.649 * *$ & $.523 * *$ & $.630 * *$ & $.511 * *$ & $.523 * *$ & $.470 * *$ & $.330 * *$ & 1 & & & \\
\hline Valor3 & -0.13 & -0.134 & -0.129 & -0.043 & -0.134 & -0.124 & -0.192 & 0.082 & 1 & & \\
\hline Beta3 & 0.217 & 0.151 & 0.203 & $.228^{*}$ & 0.151 & 0.175 & $.258 *$ & -0.027 & 0.008 & 1 & \\
\hline Logcapital3 & $.404 * *$ & $.260 *$ & $.454^{* *}$ & $.330 * *$ & $.258 *$ & $.252 *$ & $.475 * *$ & 0.178 & $-.397 * *$ & $.274 *$ & 1 \\
\hline
\end{tabular}

Table 3: Correlations between explanatory and control variables

Therefore, the inclusion of one of those explaining variables into the model results in the need to exclude others, since they are correlated. On the other hand, the majority of the control variables, Valor3 and Beta3, do not have considerable correlation coefficients. The variable logcapital3 is correlated with almost all explanatory variables, but the coefficients are relatively acceptable.

\section{Logistic regression analysis}

Through the many different models of logistic regression analysis, it was possible to identify statistically significant results, indicating the probability of implication of stock profitability, in the year following the disclosure of information, according to each category of intangible resources. In none of the statistically significant models has Capital3, the variable indicating the level of capitalization, been confirmed, as shown below.

Model 1: Rentadic3 $=\beta_{0}+\boldsymbol{\beta}_{\mathbf{1}}$ Dtri2 $+\beta_{2}$ Beta3 $+\beta_{3}$ Capital3 $+\beta_{4}$ Valor3 $+\varepsilon$

The explanatory variable, representing the extent of disclosure of the total of intangible resources, shows the value of LR statistic (maximum verisimilitude) of 
13.22554 , at $1 \%$ of significance, with all the statistically significant variables. This indicates that there is the probability of implication between the extension of total disclosure of intangible resources, in 2002, and the profitability of stock, in the following year. Furthermore, a higher Beta value for one given company increases the probability of greater stock profitability as compared to the set's average. It also implies that there is a probability that increased results for the accounting value divided by the price of stock will cause a decrease of its profitability.

\begin{tabular}{|c|c|c|c|c|c|}
\hline Model 1 & \multicolumn{2}{|c|}{ Dependent Variable: Rentadic3 } & $\begin{array}{l}\text { Obs with Dep }=1 \\
\text { Obs with Dep }=0\end{array}$ & $\begin{array}{l}36 \\
44\end{array}$ & Total obs 80 \\
\hline Explaining Variables & Coefficient & Prob. & & & $\begin{array}{l}\text { McFadden } \\
\text { R-squared }\end{array}$ \\
\hline Beta3 & 2.167007 & 0.0503 & & & 0.120121 \\
\hline Valor3 & -1.495014 & 0.0283 & & & \\
\hline Dtri2 & -0.033431 & 0.0848 & & & \\
\hline LR statistic (3 df) & 13.22554 & Probabili & 0.004173 & & \\
\hline
\end{tabular}

Table 4: Disclosure of total of intangible resources

Differences between the reviewed body of works and the present study notwithstanding, Botosan's (1997) research is especially relevant, which, analyzing 122 manufacturing companies, with stock in the American market, shows that the extent of information disclosure, with a low level of analysis by researchers, is negatively related to capital costs, with a coefficient of $R^{2} 16.5 \%$ of explanation. However, when the level of analysis by researchers is higher, the results do not indicate a statistically significant relationship between the extent of information disclosure and the cost of capital for the liquid assets.

In another study, Botosan and Plumlee (2001) have shown that the extent of disclosure in the annual report reduces the cost of capital, with a statistically significant model at $R^{2} 6.26 \%$. On the other hand, Richard and Welker (2001) have shown that extent of disclosure concerning financial information reduces the cost of capital, at $R^{2} 8.4 \%$. Hail (2002) confirms these findings, establishing that the extent of disclosure in the annual reports of Swiss companies is negatively related to the cost of capital, with an explanatory coefficient of $\mathrm{R}^{2} 38.1 \%$.

Gietzmann and Ireland (2003) studied the relationship between the extent of disclosure of financial information and the cost of capital. The results have shown that companies from the United Kingdom, known for their aggressiveness in the market, have reduced their costs by increasing the extent of disclosure. However, 


\section{Intangible Capital}

when companies are conservative, there has been no ratified relationship between the disclosure of information and the cost of capital.

With different results, Espinosa and Trombetta (2004) have not ratified a clear inverse relationship between the extent of disclosure and the cost of capital, when they analyzed a sampling of companies of the Spanish market. With similar results, Alencar and Lopes (2005) were unable to confirm that the degree of eligibility to the Transparency Prize - which represents the extent of disclosure of Brazilian companies - has any influence in the cost of capital.

Model 2: Rentadic3 $=\beta_{0}+\boldsymbol{\beta}_{1}$ Dce2 $+\beta_{2}$ Beta3 $+\beta_{3}$ Capital3 $+\beta_{4}$ Valor3 $+\varepsilon$

As above, Model 2 shows an LR statistic of 15.08351 , at $1 \%$ of signification, presenting statistically significant variables, indicating the probability of implication between the profitability of company stock, in the year following disclosure of information on structural capital (Dce2). There is also the probability of implication with the Beta and the accounting value of stock / price. The three variables present a level of significance lower than $5 \%$. In this sense, the model shows the probability of a relationship between the extent of disclosure of information on structural capital, in 2002, and the profitability of company stock in the following year.

\begin{tabular}{|c|c|c|c|c|c|}
\hline Model 2 & \multicolumn{2}{|c|}{ Dependent Variable: Rentadic3 } & $\begin{array}{l}\text { Obs with Dep }=1 \\
\text { Obs with Dep }=0\end{array}$ & $\begin{array}{l}36 \\
44\end{array}$ & Total obs 80 \\
\hline Explaining Variables & Coefficient & Prob. & & & adden R-squared \\
\hline Beta3 & 2.266854 & 0.0409 & & & 36996 \\
\hline Valor3 & -1.495313 & 0.0292 & & & \\
\hline Dce2 & -0.038711 & 0.0329 & & & \\
\hline LR statistic (3 df) & 15.08351 & $\begin{array}{l}\text { Probabilit } \\
0.00174\end{array}$ & (LR statu) & & \\
\hline
\end{tabular}

Table 5: Disclosure of information on structural capital

In this sense, the model shows that there is the probability of a relationship between the extent of disclosure on structural capital, in 2002, and the profitability of stock in the following year.

Model 3: Rentadic3 $=\beta_{0}+\boldsymbol{\beta}_{\mathbf{1}}$ Dcr2 $+\beta_{2}$ Beta3 $+\beta_{3}$ Capital3 $+\beta_{4}$ Valor3 $+\varepsilon$ 


\begin{tabular}{|c|c|c|c|}
\hline Model 3 & $\begin{array}{l}\text { Dependent Variable: } \\
\text { Rentadic3 }\end{array}$ & $\begin{array}{l}\text { Obs with } \operatorname{Dep}=1 \\
\text { Obs with } \operatorname{Dep}=0\end{array}$ & Total obs 80 \\
\hline Explaining Variables & Coefficient & Prob. & McFadden R-squared \\
\hline Beta3 & 1.985751 & 0.0666 & 0.114075 \\
\hline Valor3 & -1.531904 & 0.0260 & \\
\hline Dcr2 & -0.022365 & 0.1247 & \\
\hline LR statistic (3 df) & 12.55988 & Probability (LR stat) 0.005692 & \\
\hline
\end{tabular}

Table 6: Disclosure of information on relational capital

Model 3 shows that control variables Beta3 and Valor3 are statistically significant, and LR statistic 12.55988, at $10 \%$ significance. It does not show that Dcr2 (relational capital disclosure) is statistically relevant. Therefore, there is no probability of relationship between the explaining variable Dcr2 and the dependent variable.

In other words, there is no probability that the greater the extent of disclosure on relational capital, there will be either lesser or greater profitability of stock in the following year.

Model 4: Rentadic3 $=\beta_{0}+\boldsymbol{\beta}_{\mathbf{1}}$ Dch2 $+\beta_{2}$ Beta3 $+\beta_{3}$ Capital3 $+\beta_{4}$ Valor3 $+\varepsilon$

Model 4 presents LR statistic 10.09994 , at $1 \%$ significance. The coefficient Beta3 associated with the variable Valor3 is lower than 0.05 , but all the other coefficients are close to this limit. It demonstrates that the variables Beta3 and Valor3 are statistically significant. However, it does not show that the variable Rch2 (disclosure of Human capital) is statistically significant. The model does not show the probability of there being a relationship between the variable Rch 2 and the dependent variable Rentadic3.

\begin{tabular}{|c|c|c|c|c|}
\hline Model 4 & $\begin{array}{l}\text { Dependent Variable: } \\
\text { Rentadic } 3\end{array}$ & $\begin{array}{l}\text { Obs with Dep }=1 \\
\text { Obs with Dep }=0\end{array}$ & $\begin{array}{l}36 \\
44 \\
\end{array}$ & Total obs 80 \\
\hline Explaining Variables & Coefficient & Prob. & & McFadden R-squared \\
\hline Beta3 & 1.696620 & 0.1127 & & 0.091732 \\
\hline Valor3 & -1.447629 & 0.0320 & & \\
\hline Dch2 & -0.003032 & 0.8658 & & \\
\hline LR statistic (3 df) & 10.09994 & Probability (LR statu) 0. & 735 & \\
\hline
\end{tabular}

Table 7: Disclosure of information on human capital 
Table 7: Disclosure of information on human capital Therefore, one does not observe a probability of there being greater stock profitability in the following year for a greater disclosure of information on human capital.

Model 5: Rentadic3 $=\beta_{0}+\boldsymbol{\beta}_{\mathbf{1}}$ Dcet2 $+\beta_{2}$ Beta3 $+\beta_{3}$ Capital3 $+\beta_{4}$ Valor3 $+\varepsilon$

Model 5 is validated, with LR statistic of 12.60049 , at an admissible level of significance. The variables Beta3 and Valor3 present a level of significance around $5 \%$. The model does not show that the variable Dcet2 (extent of disclosure on Technology-related structural capital) is statistically relevant.

\begin{tabular}{|c|c|c|c|c|}
\hline Model 5 & $\begin{array}{l}\text { Dependent Varia } \\
\text { Rentadic3 }\end{array}$ & $\begin{array}{l}\text { Obs with Dep }=1 \\
\text { Obs with Dep }=0\end{array}$ & $\begin{array}{l}36 \\
44 \\
\end{array}$ & Total obs 80 \\
\hline Explaining Variables & Coefficient & Prob. & & McFadden R-squared \\
\hline Beta3 & 1.988378 & 0.0663 & & 0.114444 \\
\hline Valor3 & -1.531875 & 0.0260 & & \\
\hline Dcet2 & -0.022402 & 0.1222 & & \\
\hline LR statistic (3 df) & 12.60049 & Probability (LR statu) 0.0 & 5585 & \\
\hline
\end{tabular}

Table 8: Disclosure of information on technology-related structural capital

The model does not identify a statistically significant probability of there being a relationship between the variable representing the extent of disclosure on technology-related structural capital and the profitability in the following year.

Model 6: Rentadic3 $=\beta_{0}+\boldsymbol{\beta}_{1}$ Dceo2 $+\beta_{2}$ Beta3 $+\beta_{3}$ Capital3 $+\beta_{4}$ Valor3 $+\varepsilon$

Model 6 of logistic regression, identified in Table 9, shows that variables are statistically significant, with LR statistic 11.93551 , at $1 \%$ significance. The variable Valor3 is statistically significant at $5 \%$, whereas variable Beta3, is found to have $10 \%$ significance. On the other hand, the model does not show that the variable Dceo2 (disclosure of organizational structural capital) has statistically significant values.

\begin{tabular}{|c|c|c|c|c|}
\hline Model 6 & $\begin{array}{l}\text { Dependent Variable: } \\
\text { Rentadic3 }\end{array}$ & $\begin{array}{l}\text { Obs with Dep }=1 \\
\text { Obs with Dep }=0\end{array}$ & $\begin{array}{l}36 \\
44\end{array}$ & Total obs 80 \\
\hline Explaining Variables & Coefficient & Prob. & & McFadden R-squared \\
\hline Beta3 & 1.967616 & 0.0693 & & 0.108404 \\
\hline Valor3 & -1.512969 & 0.0274 & & \\
\hline Dceo2 & -0.018550 & 0.1799 & & \\
\hline LR statistic (3 df) & 11.93551 & Probability (LR statu) & 007607 & \\
\hline
\end{tabular}


Therefore, one does not observe a probability of there being greater stock profitability in the following year for a greater disclosure of information on organizational structural capital.

Model 7: Rentadic3 $=\beta_{0}+\boldsymbol{\beta}_{\mathbf{1}}$ Dcrn2 $+\beta_{2}$ Beta3 $+\beta_{3}$ Capital3 $+\beta_{4}$ Valor3 $+\varepsilon$

Model 7 presents logistic regression validated with LR statistic of 14.15035 , at $1 \%$ significance. The variables: Beta3 and Valor 3 are statistically significant at $5 \%$ and the variable Dcrn2, at $10 \%$. This leads us to recognize the probability of there being a decrease in stock profitability in the following year for a greater disclosure of information on business-related relational capital.

\begin{tabular}{|c|c|c|c|c|}
\hline Model 7 & $\begin{array}{l}\text { Dependent Variable: } \\
\text { Rentadic3 }\end{array}$ & $\begin{array}{l}\text { Obs with Dep }=1 \\
\text { Obs with Dep }=0\end{array}$ & $\begin{array}{l}36 \\
44 \\
\end{array}$ & Total obs 80 \\
\hline Explaining Variables & Coefficient & Prob. & & McFadden R-squared \\
\hline Beta3 & 2.323017 & 0.0402 & & 0.128520 \\
\hline Valor3 & -1.613481 & 0.0214 & & \\
\hline Dcrn2 & -0.036225 & 0.0529 & & \\
\hline LR statistic (3 df) & 14.15035 & $\begin{array}{l}\text { Probability (LR } \\
\text { statu) } 0.002707\end{array}$ & & \\
\hline
\end{tabular}

Table 10: Disclosure of information on Business-related relational capital

Model 8: Rentadic3 $=\beta_{0}+\boldsymbol{\beta}_{\mathbf{1}}$ Dcrs2 $+\beta_{2}$ Beta3 $+\beta_{3}$ Capital3 $+\beta_{4}$ Valor3 $+\varepsilon$

Model 8 is validated with LR statistic 13.06016 , at $1 \%$ significance. The model shows that the variables Beta3, Valor3 and Dcrs2 are statistically significant at $10 \%$. This allows us to recognize the probability of greater stock profitability for greater extent in disclosure of information on social relational capital. Regardless of differences in the nature of our study, the results confirm the findings of Richard and Welker (2001), who validated a model indicating a relationship between the disclosure of social information and the cost of capital, at a coefficient $R^{2} 9.9 \%$.

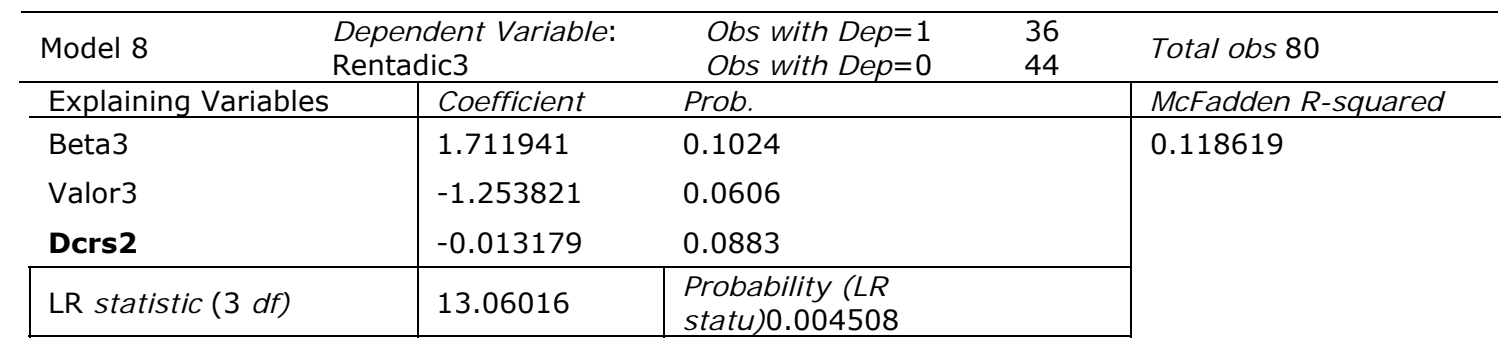

Table 11: Disclosure of information on social relational capital 
Considering these statistical results, the hypothesis may be accepted that there is the probability of a relationship between the extent of information disclosure on intangible resources and the profitability of stock, for companies which have obtained results above sample average, in the following year. The explanatory relationship is negative, i.e. there is the probability, albeit low, of lesser gains associated to greater extent in disclosure. In this sense, disclosing intangible resources may lead to greater costs for the stockholder. The same happens when disclosure refers to structural capital, as a category, and to business-related and social relational capital, as subcategories. On the other hand, the hypothesis has not been confirmed when related to the disclosure of information on human capital, relational capital, technology-related structural capital, and organizational capital, when those are analyzed individually.

\section{Final considerations}

The present study contributes by providing direct evidence to support the hypothesis that there is a connection between the extent of information disclosure on intangible resources and the profitability of stock in the following year, for companies obtaining results above sample average. The results are relevant, considering that profitability may be explained by other variables.

The empirical results of the present study do not support the assumption that, for capital markets, the absence of information is bad information (Lev, 2003). This is due to the fact that, somehow, the decision to disclose information on intangible resources may lead to lower profitability levels, whether due to negative appraisals by investors, or because investors find that the stock is overpriced. Taking into account the fact that investments on intangible resources are generally very expensive, in the first stages of a process of innovation, as well as the risk associated to their technological and commercial viability (Lev, 2003), one may consider that there is the probability that investors, to a certain extent, do not appreciate risks, when it comes to this kind of information.

It is important to remember that the present study is different from other reviewed research projects in two basic aspects. First, the reviewed studies analyze the cost of capital, an ex-ante perspective, whereas our research project analyzes stock profitability (ex-post). The second point refers to the variables that represent the 
disclosure of information. In all reviewed studies, the analyzed information did not concern intangible resources, as in our case. Intangible resources may be a competitive advantage for the company. This difference is essential when one wishes to identify the assumptions upon which the problematic of disclosure is based, which, on the one hand, considers that disclosing information may reduce the costs of a transaction, but which, on the other hand, would lead to extra costs for the owner.

The results of this research lead to think that the market may give a positive value, not to the amount of disclosed information on intangible resources, but rather to the impact of an intangible resource on a market "reality". In this sense, the extent of this research would refer to the use of other methodological perspectives. It is also important to replicate the present study upon companies from other markets, since the present study is limited to the Spanish market. A sampling of companies from stock markets with a greater number of actors, or in different countries, would allow us to identify the specificities of different markets.

Although the obtained results are not described, the present study also analyzed the impact of disclosure in the year 2002 over the profitability of stock in 2004. The same methodology was adopted for calculating profitability, and the same data sources were used. The variation from the presented models was limited to values of the dependent variable and of the control variables, corresponding to the year 2004, whereas the values of the explanatory variables were kept the same, related to the year 2002. The models did not present statistically significant results, in any of these cases. This led us to conclude that there is no impact of disclosure in 2002 over profitability in 2004 . Therefore, considering the possibility of a variation of the implication of information disclosure over the profitability of stock, it would be convenient to analyze the greater sampling in terms of years, which would lead to a greater understanding about the sensitivity of the market to the variation in the extent of voluntary information disclosure, especially concerning intangible resources.

Finally, it is important to expand the present study to encompass other data sources, such as the specialized press, meetings with analysts, and the company's page on the Internet, among other communication channels, although the annual report remains the main official channel between the direction of a company and 


\section{- Intangible Capital}

the market, besides being the most frequent object of study in empirical research. However, the market may make use of other channels disclosing information on intangible resources. The present study, along with all other similar studies, does not take into consideration the intangible passives. If this information were to be analyzed, a wider perspective could be obtained about the probability of implication between the extent of information disclosure and the stock profitability in the following year, since the resources and the disclosure of intangible passives may influence the profitability of company stock.

\section{References}

ABOODY, D.; LEV, B. (2000). Information asymmetry, R\&D, and insider gains. The Journal of Finance, (LV):2747-2766.

ALENCAR, R.; LOPES A. (2005). Custo do capital próprio e nível de disclosure nas empresas brasileiras. Working paper. 5o. Congresso USP de Controladoria e Contabilidade.

AKERLOF, G. (1970). The market for lemons: quality uncertainty and the market mechanism. The Quarterly J ournal of Economics, (84):488-500.

APPELLÁNIZ, P.; SARDOYA, A. (1995). La publicación de información por segmentos no regulada: perfil característico de las empresas españolas. Working paper. VIII Congreso de AECA.

ARROW, K. (1962). Economic welfare and the allocation of resources for invention. The Rand Corporation, 609-625.

ARROW, K. (1963). Uncertainty and the welfare economics of medical care. The American Economic Review, (LIII):1-9.

BOTOSAN, C. (1997). Disclosure level and the cost of equity capital. The Accounting Review, (72):323-349.

BOTOSAN, C.; PLUMLEE, M. (2002). A re-examination of disclosure level and the expected cost of equity capital. J ournal of Accounting Research, (40):21-40. 


\section{- Intangible Capital}

(C) (c) Intangible Capital, 2009 - 5(1): 1-32 - ISSN: 1697-9818 doi: 10.3926/ic.2009.v5n1.p1-32

BREALEY, R.; MYERS, S. (2005). Financiamento e gestão de risco. Porto Alegre. Ed. Bookman.

CAMFFERMAN, K. (1997). Voluntary annual report disclosure by listed Dutch companies. New York. Ed. Garland Publishing.

CAÑIBANO, L.; GARCÍA-AYISO, M.; SÁNCHEZ, P. (2000). Accounting for intangibles: a literature review. Journal of Accounting Literature, (19):102-130.

CAÑIBANO, L.; SÁNCHEZ, P.; GARCÍA-AYISO, M.; CHAMINADE， C. (2002). Guidelines for managing and reporting on intangibles (Intellectual capital report). Proyecto Meritum.

CHOW, C.; WONG-BOREN, A. (1987). Voluntary financial disclosure by Mexican corporations. The Accounting Review, (LXII, 3):533-541.

CHRISTOPHER, T.; HASSAN, S. (1995). Voluntary disclosure of cash for information: Australian Evidence. Working paper. BAA Conference. Bristol.

COASE, R. (1971). Corporations and conscience: The issues. In D. Bell, R. Coase, M. Greenberger and E. Parker, 1971. Sloan Management Review, 1-24.

COELHO NETTO, J. T. (1990). Semiótica, informação e comunicação. São Paulo: Editora Perspectiva.

COOKE, T. E. (1989). Disclosure in the corporate annual reports of Swedish companies. Accounting and Business Research, (19):3-124.

COOKE, T. E. (1992). The impact of size, stock market listing and industry type on disclosure in the annual reports of Japanese listed corporations. Accounting and Business Research, (22):229-237.

COPELAND, T.; GALAI, D. (1983). Information effects on the bid-ask spread. The J ournal of Finance, (38):1457-1469.

COPELAND, T.; WESTON J.; SHASTRI, K. (2005). Financial theory and corporate policy. Madrid. Ed. Pearson. 


\section{- Intangible Capital}

CORE, J. (2001). A review of the empirical disclosure literature: discussion. Journal of Accounting and Economics, 441-456.

DARROUGH, M.; STOUGHTON, N. (1990). Financial disclosure policy in an entry game. Journal of Accounting and Economics, (12):219-243.

DEMSETZ, H. (1967). Toward a theory of property rights. American Economic Review, (57):347-359.

DEPOERS, F. (2000). A cost-benefit study of voluntary disclosure: some empirical evidence from French listed companies. European Accounting Review: 245 - 263.

DIAMOND, D.; VERRECCHIA, R. (1991). Disclosure, liquidity, and cost of capital. The Journal of Finance, (XLVI):1325-1359.

DYE, R. (1986). Proprietary and Nonproprietary disclosures. The Journal of Business, (59):331-366.

ESPINOSA, M.; TROMBETTA, M. (2004). Interacción entre la divulgación de información y el coste de capital: evidencia para el mercado español. Working paper. Universidad Carlos III de Madrid.

FIELDS, T.; LYS, T.; VINCENT, L. (2001). Empirical research on accounting choice. Journal of Accounting and Economics, 255-307.

FIRER, S.; WILLIAMS, M. (2006). Association between ownership structures of Singapore publicly traded firms and intellectual capital disclosure. Corporate Governance and Intellectual Capital Archive, 1-31.

FIRTH, M. (1984). The extent of voluntary disclosure in corporate annual reports and its association with security risk measures. Applied Economics, (16):269-268.

FISHMAN, M.; HAGERTY, K. (1988). Disclosure decisions by firms and the competition for price efficiency. The Journal of Finance, (44):633-646.

GARCÍA, M.; MONTERREY, J. (1993). La revelación voluntaria en las compañías españolas cotizadas en bolsa. Revista Española de Financiación y Contabilidad: 53-70. 


\section{- Intangible Capital}

(C) (C) Intangible Capital, 2009 - 5(1): 1-32 - ISSN: 1697-9818 doi: 10.3926/ic.2009.v5n1.p1-32

GARCÍA-MECA; MARTÍNEZ, I. (2004). Divulgación voluntaria de informação empresarial: índices de revelación. Partida Doble, 66-77.

GIETZMANN, M.; IRELAND, J. (2003=. Cost of capital, strategic disclosures and accounting choice. Working paper. London School of Economics.

GLOSTEN, L.; MILGRON, P. (1985). Bid, ask and transaction prices in a specialist market with heterogeneously informed traders. Journal of Financial Economics: 71-100.

GÓMEZ, J.; IÑIGUEZ, R.; POVEDA, F. (2006). Revelación voluntaria de informação y características das sociedades cotizadas no mercado de capital español. Revista Española de Financiación y Contabilidad, (131):8-32.

HAIL, L. (2002). The impact of voluntary corporate disclosures on the ex-ante cost of capital for Swiss firms. The European Accounting Review, 741-773.

HEALY, P.; PALEPU, K. (1999). A review of the voluntary disclosure literature. Working paper. 2000 JAE Conference, 1-31.

HOSSAIN, M.; PERERA, M.; RAHMAN, A. (1995). Voluntary disclosure in the annual reports of New Zealand companies. Journal of International Financial Management $\&$ Accounting, (6):69-88.

HUGHES, P. (1986). Signaling direct disclosure under asymmetric information. Journal of Accounting and Economics, 119-142.

JENSEN, M.; MECKLING, W. (1976). Theory of the firm: managerial behavior, agency costs and ownership structure. Journal of Financial Economics, 305-360.

KING, R.; WALLIN, D. (1995). Experimental tests of disclosure with an opponent. Journal of Accounting and Economics, 139-167.

LAMBERT, R.; LEUZ, C.; VERRECCHIA, R.E. (2006). Accounting information, disclosure, and the cost of capital. Journal of Accounting Research, 1-46.

LEV, B. (1992). Information disclosure and strategy. California Management Review, 9(32). 
LEV, B. (1997). Commentary. Accounting Horizons, (11):136-138.

LEV, B. (2003). Intangibles: Medición, Gestión e Información. Barcelona, Ed. Deusto.

LEVENTIS, S.; WEETMAN, P. (2000). Exploring and Explaining Variations in Voluntary Disclosure in a European Emerging Capital Market: Evidence from the Athens Stock Exchange. Working paper, BAA[S] 2000 Regional Conference University of Aberdeen.

MACAGNAN, C. B. (2005). Factores explicativos da revelación de información de activos intangibles de empresas que cotizan en España. Trabajo de Investigación. Universidad Autónoma de Barcelona.

MARR, B. (2005). Perspectives on intellectual capital. London. Ed. Elsevier.

NAGAR, V.; NANDA, D.; WYSOCKI, P. (2003). Discretionary disclosure and stockbased incentives. Journal of Accounting and Economics, (34):283-309.

PRENCIPE, A. (2004). Proprietary costs and determinants of voluntary segment disclosure: evidence from Italian listed companies. The European Accounting Review, (13.2):319-340.

RAFFOURNIER, B. (1995). The determinants of voluntary financial disclosure by Swiss listed companies. The European Accounting Review, (4):261-280.

RICHARDSON, A.; WELKER, M. (2001). Social disclosure, financial disclosure and the cost equity capital. Accounting, Organizations and Society, (26):597-616.

ROOS, G.; PIKE, S.; FERNSTRÖM, L. (2005). Managing intellectual capital in practice. London. Ed. Elsevier.

SÁNCHEZ, P.; CAÑIBANO, L.; GARCÍA-AYUSO, M.; CHAMINADE, C.; OLEA, M.; ESCOBAR, C. (2000). Mensuring intangibles to understand and improve innovation management. Spanish exploratory case studies. Meritum Metting, Sevilla 27-29 January 2000.

SENGUPTA, P. (1998). Corporate disclosure quality and the cost of debt. The Accounting Review, (73):459-474. 
SUÁREZ, A. (2003). Decisiones óptimas de inversión y financiación en la empresa. 20a. Ed. Madrid. Pirámide.

SVEIBY, K. (2000). La nueva riqueza de las empresas. Barcelona. Ed. Gestión.

VERGAUWEN, P.; ALEM, F. (2005). Annual report IC disclosures in the Netterlands, France and Germany. Journal of Intellectual Capital, 89-104.

VERRECCHIA, R. (1983). Discretionary disclosure. Journal of Accounting and Economics, 179-194.

WAGENHOFER, A. (1990). Voluntary disclosure with a strategic opponent. Journal of Accounting and Economics, 341-363.

WATSON, A.; SHRIVES, P.; MARSTON, C. (2002). Voluntary disclosure of accounting ratios in the UK. British Accounting Review, 289-313.

WILLIAMS, M. (2001). Is intellectual performance and disclosure practices related? Journal of Intellectual Capital, (2):192-203.

WILLIAMS, M. (2002b). The theory of the firm as governance structure: from choice to contract. J ournal of Economic Perspectives, (16):171-195.

\section{Appendix 1: Companies in the sampling}

\begin{tabular}{|c|c|c|c|c|}
\hline Abengoa & Cementos Molins & Española Del Zinc & Urbis & Sol Meliá \\
\hline Abertis & Cementos Portland & Europ istas & Jazz Telecom & SOS \\
\hline Acciona & Carrefour & FCC & La Seda & Tecnocom \\
\hline Aceralia & Cia Diretores Log ista & Funespana & Metrovacesa & Telefónica Moviles \\
\hline Acerinox & CEP & Gamesa CT & MS Ponferrada & Telefónica PI \\
\hline ACS & Cia EVA & Gas Natural SDG & $\mathrm{NH}$ & Telefónica \\
\hline Adolfo Dominguez & $\mathrm{CLH}$ & ENCE & Obrascon & Telepizza \\
\hline Aguas de Valencia & $\mathrm{CAF}$ & Ferrovial & PC de Europa & Testa \\
\hline Aldeasa & Cortefiel & Inmocaral & Prisa & Transp. Azkar \\
\hline Altadis & Dogi & Hullas & Prosegur & Tubacex \\
\hline Amadeus & Dragados & Iberdrola & Puleva Biotech & Tubos Reunidos \\
\hline Amper & Duro Felguera & Iberia & Recoletos & Union Fenosa \\
\hline Arcelor & EADS & Iberpapel & REE & Unipapel \\
\hline Azkoyen & Ebro Puleva & Indo & Repsol YPF & Uralita \\
\hline Baron de Ley & Elecnor & Indra & S.A. Hullera & Vidrala \\
\hline Befesa & Enagas & Ind Diseno Textil & Sacyr & Viscofan \\
\hline Bodegas Riojanas & Endesa & Colonial & SPS & Zardoya Otis \\
\hline $\begin{array}{l}\text { Campofrio } \\
\text { Cementos Lemona }\end{array}$ & $\begin{array}{l}\text { EI Aragonesas } \\
\text { Ercros }\end{array}$ & Del Sur & AGBAR & Zeltia \\
\hline
\end{tabular}




\section{Appendix 2: Categories and subcategories, with their respective indicators representing intangible resources}

\begin{tabular}{|c|c|}
\hline Category of HUMAN CAPITAL indicators & $\%$ \\
\hline Number of employees & 89.4 \\
\hline Evolution of the number of employees in recent years & 47.9 \\
\hline Number of layoffs & 12.8 \\
\hline Number of newly hired employees & 21.3 \\
\hline Number of missed workdays & 11.7 \\
\hline External mobility of personnel & 44.7 \\
\hline Internal mobility of personnel & 16.0 \\
\hline Seniority segmentation of personnel & 11.7 \\
\hline Function segmentation of personnel & 8.5 \\
\hline Age segmentation of personnel & 21.3 \\
\hline Educational level segmentation of personnel & 0.0 \\
\hline Gender segmentation of personnel & 6.4 \\
\hline Regional segmentation of personnel & 6.4 \\
\hline Description of training and educational activities & 7.4 \\
\hline Hours spent on training and ed ucational activities & 54.3 \\
\hline Expenditure on training and educational activities & 36.2 \\
\hline Employees that took part in training or educational activities & 11.7 \\
\hline Recruiting policies & 39.4 \\
\hline $\begin{array}{l}\text { Salary policy and system } \\
\text { Career plan }\end{array}$ & $\begin{array}{l}10.6 \\
5.3\end{array}$ \\
\hline Incentive program & 7.4 \\
\hline Social benefits and programs & 8.5 \\
\hline Security and hygiene-related policies & 14.9 \\
\hline Information about agreements with unions & 39.4 \\
\hline Employees' level of satisfaction & 10.6 \\
\hline Productivity or profitability per employee & 2.1 \\
\hline Earnings per employee & 4.3 \\
\hline Work experience of main directors in other companies & 2.1 \\
\hline Training of main directors & 4.3 \\
\hline Newly hired directors & 0.0 \\
\hline $\begin{array}{l}\text { Category of STRUCTURAL CAPITAL indicators }=\text { (Technology-related structural capital }+ \\
\text { Organizational structural capital) }\end{array}$ & $\%$ \\
\hline \multicolumn{2}{|l|}{ Subcategory of TECHNOLOGY-RELATED STRUCTURAL CAPITAL indicators } \\
\hline Description and reasons for investment on information technologies & 20.2 \\
\hline Description of investments on hardware & 8.5 \\
\hline Cost of investments on hardware & 4.3 \\
\hline Description of investments on software & 17.0 \\
\hline Cost of investments on software & 6.4 \\
\hline Policy, strategy and / or objectives of I+D activities & 45.7 \\
\hline Competitive force of $I+D$ activities compared to competitors & 40.4 \\
\hline Future perspectives related to $\mathrm{I}+\mathrm{D}$ & 45.7 \\
\hline Expenditure on $I+D$ & 33.0 \\
\hline Number of employees involved in I+D & 5.3 \\
\hline Number of patents, licenses, etc. & 12.8 \\
\hline $\begin{array}{l}\text { Pending patents, licenses, etc. } \\
\text { Details on patents or licenses }\end{array}$ & $\begin{array}{l}7.4 \\
12.8\end{array}$ \\
\hline New products & 51.1 \\
\hline Projects or products under development & 58.5 \\
\hline Prices of marketed products & 10.6 \\
\hline Phase of product lifecycle & 40.4 \\
\hline Characteristics of offered products & 88.3 \\
\hline Indicators of productive efficiency & 61.7 \\
\hline Indicator of the state of the production technology used & 62.8 \\
\hline Installed capacity & 30.9 \\
\hline Used capacity & 30.9 \\
\hline Image of brand(s) & 40.4 \\
\hline Category of ORGANIZATIONAL STRUCTURAL CAPITAL indicators & $\%$ \\
\hline Numbers indicating the level of informatization (number of computers, etc.) & 9.6 \\
\hline Data on information systems (databases, number of people with computer access, etc.) & 17.0 \\
\hline Personnel devoted to information technologies & 2.1 \\
\hline Improvements adopted in processes and in organization for the period in question & 68.1 \\
\hline Costs of improvements adopted in processes or in organization & 36.2 \\
\hline Reasons for investment on information processes & 51.1 \\
\hline Management and control systems ad opted & 39.4 \\
\hline Numbers concerning the distribution and / or organization of work time & 0.0 \\
\hline Home work & 3.2 \\
\hline Declaration of organizational culture & 17.0 \\
\hline Policy of internal communication & 17.0 \\
\hline Organizational structure / company's organizational chart & 54.3 \\
\hline Company's history and evolution & 46.8 \\
\hline Basic strategic guidelines & 53.2 \\
\hline Competitive position in the sector & 36.2 \\
\hline $\begin{array}{l}\text { Trends in the sector } \\
\text { Comments on entry barriers }\end{array}$ & $\begin{array}{ll}23.4 \\
7.4\end{array}$ \\
\hline Comments on threats from competitors & 1.1 \\
\hline Comments on technological advantages & 21.3 \\
\hline Acquisitions & 18.1 \\
\hline Categories of RELATIONAL CAPITAL indicators $=$ Business-related relational & $\%$ \\
\hline
\end{tabular}


El artículo está con Reconocimiento-NoComercial 2.5 de Creative Commons. Puede copiarlo, distribuirlo y comunicarlo públicamente siempre que cite a su autor y a Intangible Capital. No lo utilice para fines comerciales. La licencia completa se puede consultar en http://creativecommons.org/licenses/by-nc/2.5/es/ 